\title{
On bird species diversity and remote sensing - utilizing lidar and hyperspectral data to assess the role of vegetation structure and foliage characteristics as drivers of avian diversity
}

\author{
Markus Melin, Ross A. Hill, Paul E. Bellamy and Shelley A. Hinsley
}

\begin{abstract}
Avian diversity has long been used as a surrogate for overall diversity. In forest ecosystems, it has been assumed that vegetation structure, composition and condition have a significant impact on avian diversity. Today, these features can be assessed via remote sensing. This study examined how structure metrics from lidar data and narrowband indices from hyperspectral data relate with avian diversity. This was assessed in four deciduous-dominated woods with differing age and structure set in an agricultural matrix in eastern England. The woods were delineated into cells within which metrics of avian diversity and remote sensing based predictors were calculated. Best subset regression was used to obtain best lidar models, hyperspectral models and finally, the best models combining variables from both datasets. The aims were not only to examine the drivers of avian diversity, but to assess the capabilities of the two remote sensing techniques for the task. The amount of understorey vegetation was the best single predictor, followed by Foliage Height Diversity, reflectance at $830 \mathrm{~nm}$, Anthocyanin Reflectance Index 1 and Vogelmann Red Edge Index 2. This showed the significance of the full vertical profile of vegetation, the condition of the upper canopy, and potentially tree species composition. The results thus agree with the role that vegetation structure, condition and floristics are assumed to have for diversity. However, the inclusion of hyperspectral data resulted in such minor improvements to models that its collection for these purposes should be assessed critically.
\end{abstract}

Index Terms - diversity, forest, structure, floristics, lidar, hyperspectral, ALS, bird, habitat

\section{INTRODUCTION}

TN recent research, remote sensing and ecology have, to a large extent, become inseparable. Studies assessing behavior and habitat use of wildlife or the status of wildlife

The corresponding author was funded by Finnish Cultural Foundation's personal grant (Suomen Kulttuurirahasto - www.skr.fi/en) applied via the Foundation's Post Doc Pool (http://www.postdocpooli.fi/?lang=en). Bird data collection was supported by the Wildlife Trust for Bedfordshire, Cambridgeshire and Northamptonshire. Airborne lidar and hyperspectral data were acquired by Natural Environment Research Council's (NERC) Airborne Research Facility (NERC ARF). Atmospheric correction of the hyperspectral imagery was carried out by Dr Dan Clewley at the Data Analysis Node of Plymouth Marine Laboratory. (Corresponding author: Markus Melin).

Markus Melin and Ross Hill are at Department of Life and Environmental Sciences, Bournemouth University, BH12 5BB Poole, United Kingdom. (emails: markus.melin@luke.fi (currently); rhill@bournemouth.ac.uk). Paul Bellamy is at the RSPB Centre for Conservation Science, SG19 2DL Bedfordshire, United Kingdom (e-mail: paul.bellamy@rspb.org.uk) and Shelley Hinsley is at the Centre for Ecology and Hydrology, Wallingford OX10 8BB Oxfordshire, United Kingdom (e-mail: sahi@ceh.ac.uk). habitats have been conducted with various remote sensing techniques in growing numbers [1-4]. While the topics of these studies range from individual species and habitats to global issues, the backbone is always in linking the descriptions of the habitat provided by remote sensing to the ecological question in hand. The extent to which this is successful is then partly dependent on the capabilities of the chosen remote sensing method.

A topic where remote sensing has been widely utilized is the assessment of plant and animal diversity. From the kingdom of Animalia, birds have been the most widely examined group of species in this context due to widely existing, long-term monitoring programs and because their diversity is known to correlate with overall biodiversity [5-6]. Based on this, it has been taken that remote sensing methods should be able to capture and describe whatever in the habitat drives avian diversity. To this end, many papers have noted the importance of three-dimensional vegetation structure as a determinant of avian diversity [7-11]. However, it has also been noted that a second powerful driver of avian diversity relates to the floristic characteristics of the habitat [12-14]. Both of these features can be accurately assessed with remote sensing, and in the past this has been done most often with airborne laser scanning [15] and multi- or hyperspectral imaging [16].

The usefulness of lidar in ecological studies is well established and has been reviewed focusing on habitat assessment [3], animal ecology [4], and biodiversity [17]. A key aspect is the capability of lidar to describe the threedimensional structure of vegetation in the layer under the top canopy [18-20]. Recent publications, have reported positive relationships between lidar-based metrics of understorey vegetation, in particular, and avian diversity and occurrence [21-23].

For assessing the floristic component of a habitat (dominant tree, shrub and grass species, etc.), multi- and hyperspectral data analyses are the dominant remote sensing methods. Their usefulness in vegetation studies relates to their capability to address biophysical characteristics of vegetation, such as Leaf Area Index, chlorophyll content, water content and concentration of nutrients in leaves, to name a few [16]. In forest contexts, hyperspectral data have been used to discriminate tree species from one another [24-25], to estimate canopy reflectance [26], nutrient content [27], chlorophyll 
content [28] and moisture [29]. These features, in turn, translate themselves into descriptions about the composition and health of the canopy and therefore about its quality as a habitat.

Comparative studies between lidar and multispectral remote sensing methods in assessing avian diversity have been conducted [30-33]. These have found that lidar based forest structure measures were better at explaining variation in avian diversity. However, we are not aware of studies assessing wildlife or avian diversity with hyperspectral data, or comparing its performance against the most widely used method for assessing the structural component of vegetation, i.e. lidar.

In this paper we integrate airborne lidar and hyperspectral data with data of avian diversity. The aims are to compare the capabilities of both datasets in identifying the drivers of diversity, and to gain insight about which features of vegetation structure, condition and potentially composition (when estimated from remote sensing sources) are most important for determining avian diversity.

\section{MATERIALS}

\section{A. Study area}

The study area comprised four woods located in Cambridgeshire, eastern England, a landscape dominated by intensive arable agriculture $\left(52^{\circ} 25^{\prime} 13.5^{\prime \prime} \mathrm{N}, 0^{\circ} 12^{\prime} 34.0^{\prime \prime} \mathrm{W}\right)$. The four woods were: Riddy Wood (9.4 ha), Lady's Wood (8.4 ha), Raveley Wood (7.2 ha) and Gamsey Wood (4.9 ha) (Figure 1).

The four woods are broadly similar in plant species composition, the dominant tree species being Common Ash (Fraxinus excelsior), English Oak (Quercus robur), Field Maple (Acer campestre) and elm (Ulmus spp.). The elm tends to occur in discrete patches within each wood while the other three species are well mixed. The main shrub species are Common Hazel (Corylus avellana), hawthorns (Crataegus spp.) and Blackthorn (Prunus spinosa); they are well mixed and common throughout the woods, reaching heights from one

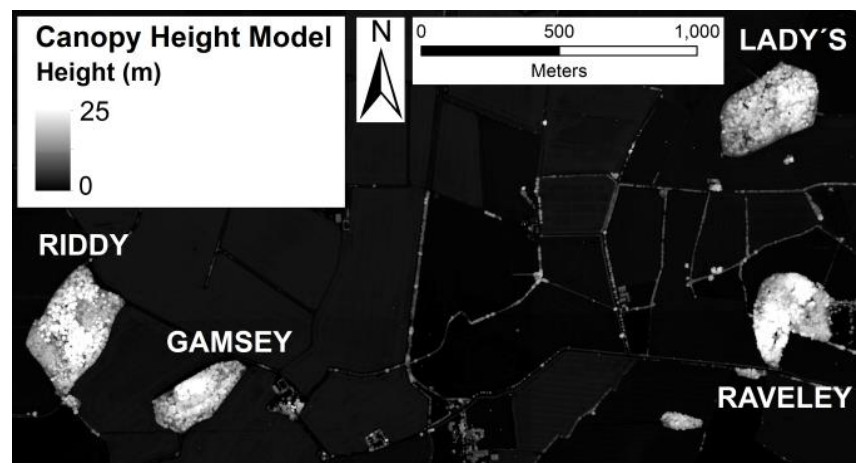

Fig 1 . The study area displayed over a lidar-based canopy height model.

to five metres. The top-canopies are dense and their height varies between 16 - 25 metres, being the smallest in Lady's. Detailed structure of the woods' vertical height profile is presented in figure 3 in [23].

\section{B. Bird data collection}

Each wood was visited four times from late March to the beginning of July in 2014. Visits started shortly after dawn and avoided weather conditions likely to depress bird activity (i.e. rain and strong winds). Birds were recorded using a spot mapping technique based on the method used in the Common Birds Census of the British Trust for Ornithology [34]. Each wood was searched systematically using a route designed to encounter all breeding territories and the surveys were done by expert bird ecologists.

All birds seen or heard were recorded on a map of the wood and the locations were later digitized. Individuals were recorded only once and in cases where the same bird was suspected to be observed twice, the second observation was omitted. A complete list of the species included in the analysis and the number of observations across the four field visits in 2014 is given in Table $\mathrm{I}$.

TABLE I

LIST OF BIRD SPECIES INCLUDED IN THE ANALYSIS

\begin{tabular}{|c|c|c|}
\hline Species & Latin name & $\begin{array}{l}\text { Number of } \\
\text { observations }\end{array}$ \\
\hline Blackbird & Turdus merula & 75 \\
\hline Blackcap & Sylvia atricapilla & 75 \\
\hline Blue tit & Cyanistes caeruleus & 239 \\
\hline Bullfinch & Pyrrhula pyrrhula & 27 \\
\hline Chaffinch & Fringilla coelebs & 104 \\
\hline Chiffchaff & Phylloscopus collybita & 39 \\
\hline Crow & Corvus corone & 11 \\
\hline Coal tit & Periparus ater & 40 \\
\hline Dunnock & Prunella modularis & 20 \\
\hline Goldfinch & Carduelis carduelis & 16 \\
\hline Garden warbler & Sylvia borin & 5 \\
\hline Great tit & Parus major & 147 \\
\hline $\begin{array}{l}\text { Great-spotted } \\
\text { woodpecker }\end{array}$ & Dendrocopos major & 38 \\
\hline $\begin{array}{l}\text { Green } \\
\text { woodpecker }\end{array}$ & Picus viridis & 22 \\
\hline Jay & Garrulus glandarius & 11 \\
\hline $\begin{array}{l}\text { Lesser } \\
\text { whitethroat }\end{array}$ & Sylvia curruca & 2 \\
\hline Long-tailed tit & Aegithalos caudatus & 54 \\
\hline Magpie & Pica pica & 17 \\
\hline Marsh tit & Poecile palustris & 23 \\
\hline Nuthatch & Sitta europaea & 3 \\
\hline Robin & Erithacus rubecula & 127 \\
\hline Song thrush & Turdus philomelos & 9 \\
\hline Stock dove & Columba oenas & 37 \\
\hline Treecreeper & Certhia familiaris & 82 \\
\hline Whitethroat & Sylvia communis & 6 \\
\hline Wren & Troglodytes troglodytes & 160 \\
\hline Yellowhammer & Emberiza citrinella & 4 \\
\hline TOTAL & & 1393 \\
\hline
\end{tabular}

\section{Remote sensing data}

Hyperspectral and lidar data were both collected on June 1st 2014 (leaf-on conditions) during a single flight using a fixedwing aeroplane flown at an altitude of $1600 \mathrm{~m}$ above ground level (agl).

The lidar sensor onboard the aircraft was a Leica ALS50-II that scanned the area with a field of view of 20 degrees, a pulse repetition frequency of $143.7 \mathrm{MHz}$ and a pulse footprint on the ground of ca. $35 \mathrm{~cm}$. The nominal sampling density in the data was 1.9 pulses per $\mathrm{m}^{2}$, but due to overlapping flight 
lines the average density in the study woods was 2.7 pulses per $\mathrm{m}^{2}$. The ALS50-II device captures a maximum of four return echoes for one emitted laser pulse with an approximate minimum vertical discrimination distance of $3.5 \mathrm{~m}$ between the echoes. All of the echo categories were used in this study. The lidar echoes were classified into ground or vegetation hits following the method of [35], as implemented in LAStools software. Next, a raster Digital Terrain Model (DTM) with a $1 \mathrm{~m}$ spatial resolution was interpolated from the classified ground hits using inverse distance weighted interpolation (IDW). This DTM was then subtracted from the elevation values ( $\mathrm{z}$-coordinates) of all the lidar returns to scale them to above ground height.

Hyperspectral data were collected with Specim's Aisa Fenix sensor. The Fenix collects data from 620 spectral bands across wavelengths between $380 \mathrm{~nm}$ and $2500 \mathrm{~nm}$. The spectral resolution is $3.5 \mathrm{~nm}$ between the wavelengths $380 \mathrm{~nm}$ and $950 \mathrm{~nm}$ and $12.5 \mathrm{~nm}$ between $970 \mathrm{~nm}$ and $2500 \mathrm{~nm}$. The sensor has a swath of 284 pixels and a field of view of 32 degrees. The flying altitude of $1600 \mathrm{~m}$ resulted in a swath width of $928 \mathrm{~m}$ and a spatial resolution of $2 \mathrm{~m}$. The hyperspectral data were processed by Plymouth Marine Laboratory with tools from their Airborne Processing Library [36]. The processing was done individually for each flight line. First, gain and offset values were used to perform radiometric calibration, which converted the 12-bit digital number values to radiance. After this, a mask file was created to omit bad pixels. Secondly, the resulting data were geocorrected and re-projected into the local coordinate system (British National Grid) after which atmospheric correction was performed using the ATCOR-4 software [37]. The woods of the study area were covered by two flight lines so that Riddy Wood, Gamsey Wood and Raveley Wood were fully within one flight line, and Lady's Wood was covered by a second flight line.

\section{METHODS}

\section{A. Calculating the metrics of avian diversity and vegetation} characteristics

For analysis purposes, the four woods were divided into ca. $30 \mathrm{~m} \times 30 \mathrm{~m}$ cells. Altogether, there were 333 of these cells. Next, the bird data and remote sensing data were extracted for these cells. All birds observed inside a cell, were used to calculate the bird diversity indices for that specific cell. The number of birds per cell ranged from 0 to 28, with 293 cells being populated.

Next, the same was done with the remote sensing data. Lidar echoes inside each cell were used to obtain cell-specific metrics describing the three-dimensional structure of the cell's vegetation (Table II). These metrics held information about the quantity and distribution of vegetation across the woods' height profiles, and have been shown to be useful in assessing wildlife habitat use and diversity in previous studies [3, 21, 22, 38]. Foliage Height Diversity (FHD) was calculated according to the formula introduced by [7]:

$$
F H D=-\sum p_{i} * \log \left(p_{i}\right)
$$

where $p_{i}$ is the proportion of lidar returns in zone $i$. The FHD was derived by binning the lidar returns into five zones according to their height: $0.50-4.00 \mathrm{~m}, 4.01-8.00 \mathrm{~m}, 8.01-$ $12.00 \mathrm{~m}, 12.01-16.00 \mathrm{~m}, 16.01-20.00 \mathrm{~m}$, and $>20 \mathrm{~m}$. The division created six nearly equal height classes in terms of how the proportion of vegetation was spread throughout the vertical profile of the woods. The height profiles of the four woods are illustrated in detail in figure 3 of [23].

Hyperspectral data were similarly used to calculate cellspecific indices related to attributes of the forest canopy function, such as stress, water-, carotenoid-, anthocyanin- and chlorophyll content, as well as the amount of leaf biomass (Table II). In addition, reflectance at $830 \mathrm{~nm}$ and $980 \mathrm{~nm}$ was included, as previous work in the study area had shown these to be the most sensitive spectral regions for determining tree species [18].

TABLE II

REMOTE SENSING METRICS USED IN THE STUDY. FOR EACH NARROWBAND INDEX, THE CALCULATED VALUES INCLUDED THE MINIMUM, MAXIMUM AND MEAN VALUE AT THE AREA OF EACH CELL.

\begin{tabular}{|c|c|c|}
\hline Dataset & Variable & Description \\
\hline \multirow[t]{9}{*}{ Lidar } & p_veg & $\begin{array}{l}\text { Proportion of vegetation hits }>0.5 \mathrm{~m} \text {. For } \\
\text { example a } p_{-} \text {veg value of } 0.5 \text { means that } 50 \% \\
\text { of the echoes in this cell came from } \\
\text { vegetation. }\end{array}$ \\
\hline & p_shrub2/4/ & Percentage of lidar returns between 0.5 and \\
\hline & $5 / 6 / 8$ & $\begin{array}{l}2 / 4 / 5 / 6 \text { or } 8 \text { metres. A } p \_s h r u b 6 \text { value of } 0.6 \\
\text { means that } 60 \% \text { of the returns from this cell } \\
\text { came from between } 0.5 \text { and } 6 \text { metres. }\end{array}$ \\
\hline & p_canopy2/ & Percentage of lidar returns above $2 / 4 / 5 / 6 / 8$ or \\
\hline & $4 / 5 / 6 / 8 / 15$ & $\begin{array}{l}15 \text { metres. A p_canopy } 8 \text { value of } 0.6 \text { means } \\
\text { that } 60 \% \text { of the returns from this cell were } \\
\text { from above } 8 \text { metres. }\end{array}$ \\
\hline & MaxH & Maximum height of the echoes in a cell. \\
\hline & $A v g H$ & Average height of the echoes in a cell. \\
\hline & $\mathrm{StdH}$ & Height standard deviation of echoes in a cell \\
\hline & $F H D$ & Foliage Height Diversity (see Equation 1) \\
\hline \multirow[t]{17}{*}{$\begin{array}{l}\text { Hyper- } \\
\text { spectral }\end{array}$} & $R S R$ & Reduced Simple Ratio \\
\hline & NDVI & Normalized Difference Vegetation Index \\
\hline & RENDVI & Red Edge Enhanced NDVI \\
\hline & VOG1 & Vogelmann Red Edge Index 1 \\
\hline & VOG 2 & Vogelmann Red Edge Index 2 \\
\hline & CRII & Carotenoid Reflectance Index 1 \\
\hline & CRI2 & Carotenoid Reflectance Index 2 \\
\hline & ARII & Anthocyanin Reflectance Index 1 \\
\hline & $A R I 2$ & Anthocyanin Reflectance Index 2 \\
\hline & $W I$ & Water Index \\
\hline & $M C A R I$ & $\begin{array}{l}\text { Modified Chlorophyll Absorption Reflectance } \\
\text { Index }\end{array}$ \\
\hline & PRI & Photochemical Reflectance Index \\
\hline & SIPI & Structure Insensitive Pigment Index \\
\hline & PSRI & Plant Senescence Reflectance Index \\
\hline & $M S I$ & Moisture Stress Index \\
\hline & $r 830^{*}$ & Reflectance at $830 \mathrm{~nm}$ \\
\hline & $r 980^{*}$ & Reflectance at $980 \mathrm{~nm}$ \\
\hline
\end{tabular}

*The reflectance at these bands has been useful in separating the dominant tree species of the study area from one another (Hill and Broughton 2010)

The remote sensing variables were expected to translate into meaningful information about, for example, availability of food or shelter for the bird species in question (based on their 
known ecology), health of the canopy, (e.g. senescence, leaf water and nutrient content), or the dominant tree species.

The remote sensing based metrics of habitat structure were then assessed against well-known metrics of diversity: the Simpson index, Shannon index, and species richness (number of different bird species), which were also calculated at the cell level. The indices were calculated from all the bird observations within each cell with these formulae:

$$
\begin{aligned}
& \text { Shannon index }=-\sum_{i=1}^{S} p_{i} * \ln \left(p_{i}\right) \\
& \text { Simpson index }=-\frac{\sum_{i=1}^{S} n_{i}\left(n_{i}-1\right)}{N(N-1)}
\end{aligned}
$$

For the Shannon index, $p_{i}$ represents the proportion of species $i$ in relation to total number of birds observed in this cell and $l n$ is a natural logarithm. For the Simpson index, $i$ is an individual species and $n$ is the total number of observations of species $i$ in this cell, while $N$ is the total number of bird observations in this cell. Both indices were chosen because they have been used widely in the context of estimating diversity, and because they ultimately differ in their interpretations: Simpson's index represents the probability that two randomly chosen individuals belong to different species, while Shannon's index represents the uncertainty in predicting the species for an observation; in a highly diverse community

TABLE III

FORMULAE USED TO CALCULATE THE SPECTRAL INDICES OF TABLE II. $R$ REFERS TO THE REFLECTANCE AT THE GIVEN BAND (NM)

\begin{tabular}{llc}
\hline \hline Index & \multicolumn{1}{c}{ Formula } & Reference \\
\hline NDVI & $(r 800-\mathrm{r} 670) /(r 800+\mathrm{r} 670)$ & {$[40]$} \\
RENDVI & $(r 705-r 750) /(r 705+r 750)$ & {$[41]$} \\
RSR & $(r 800 / r 670) *((r 1610 \mathrm{max}-r 1610) /$ & {$[42]$} \\
VOG1 & $(r 1610 \mathrm{max}-r 1610 \mathrm{~min}))$ & {$[43]$} \\
VOG2 & $(r 70 / r 720-r 747) /(r 715+r 726)$ & {$[43]$} \\
CRI1 & $(1 / r 510)-(1 / r 550)$ & {$[44]$} \\
CRI2 & $(1 / r 510)-(1 / r 700)$ & {$[44]$} \\
ARI1 & $(1 / r 550)-(1 / r 700)$ & {$[45]$} \\
ARI2 & $r 800 * A R I \_1$ & {$[45]$} \\
WI & $r 900 / r 970$ & {$[29]$} \\
MCARI & {$[((r 700-r 670)-(0.2 *(r 700-r 550))] *$} & {$[28]$} \\
PRI & $(r 700 / r 670)$ & {$[46]$} \\
SIPI & $(r 531-r 570) /(r 531+r 570)$ & {$[46]$} \\
PSRI & $(r 680-r 545) /(r 800+r 680)$ & {$[47]$} \\
MSI & $r 1600 / r 820$ & {$[48]$} \\
& & \\
\hline
\end{tabular}

the uncertainty is higher than in a community dominated by only a few species [39]. From now on, the indices are referred to as Shannon and Simpson. Formulae used for deriving the spectral indices, as well as their sources, are presented in Table III.

\section{B. Modeling relationships between avian diversity and vegetation characteristics}

The relationships between bird diversity and the remote sensing metrics were examined with best subset regression. First, the best models with one to six predictor variables were identified separately for lidar (LidarModels) and hyperspectral (HyperModels) data. This resulted in six lidar models and six hyperspectral models: i.e. the best lidar model with one variable, with two variables, etc. The purpose of this analysis was to gain insight into which lidar and hyperspectral variables best relate with bird diversity. After this, the best LidarModel and the best HyperModel were selected from the six available options based on their AIC score [49].

Next, the best lidar and hyperspectral predictors (i.e. the ones that appeared most often in the models stated above) were combined to attain the best combination models (CombiModels) with, again, one to six variables. The purpose here was to gain insight into what component of the vegetation drives diversity more: foliage characteristics (hyperspectral) or structure (lidar). Finally, these six models were also compared against one another, based on their AIC score, to obtain the single best CombiModel.

The variable selection for each model was done exhaustively pending that multi-collinear and non-significant variables were not allowed, which means that for example, a lidar model with six predictors was not created if the sixth added variable was non-significant or correlated strongly with the other variables already present in the model. In comparing the models based on the AIC, a model with more variables was only rated as 'better' if it reduced the AIC by at least two [50]. All the analysis was done in $\mathrm{R}$ [51] with the packages leaps [52] and lmfor [53], where functions from the latter were used to examine and confirm that there was no significant non-normality or heteroscedasticity in the model residuals. The relationships between the best individual predictor variables and the metrics of avian diversity were also examined visually using the packages ggplot [54] and cowplot [55].

\section{RESULTS}

\section{A. Lidar metrics and avian diversity}

The lidar metrics most often chosen in the models related to the amount of understorey vegetation between ground and eight metres ( $\left.p \_s h r u b 8\right)$ and the distribution of the vegetation across the full vertical profile of the woods (FHD). These features were positively related to bird diversity, and the results were highly consistent between the different metrics. The variable p_shrub8 correlated positively with all the diversity indices, with $\mathrm{r}=0.39$ for SpeciesN, 0.34 for Shannon and 0.19 for Simpson. The variable was also always a significant predictor $(\mathrm{p}<0.05)$ of all the diversity metrics. Table IV shows the results from the best subset regression carried out with lidar predictors, while Table V shows the best LidarModels for each diversity metric as rated by AIC score. The linear relationships that the two best lidar-based predictors, $F H D$ and $p \_s h r u b 8$, had with the number of bird species is illustrated in Figure 2. As the results between the different diversity metrics were consistent, only Species $N$ is shown for reference 
TABLE IV

THE RESULTS FROM BEST SUBSET REGRESSION WHERE BIRD DIVERSITY METRICS WERE MODELLED WITH LIDAR PREDICTORS (LIDARMODELS). THE SUBSET NUMBER INDICATES THE NUMBER OF VARIABLES ALLOWED, AND THE VARIABLES LISTED FOR THAT MODEL WERE SELECTED AS THE MOST POWERFUL PREDICTORS BASED ON EXHAUSTIVE SEARCH. ALL PREDICTORS ARE SIGNIFICANT AT P $<0.05$. THE AIC VALUE OF THE FINAL MODEL IS UNDERLINED AND IN BOLD.

\begin{tabular}{|c|c|c|c|}
\hline Index & $\begin{array}{l}\text { Sub- } \\
\text { set }\end{array}$ & Formula & Model AIC \\
\hline \multirow[t]{4}{*}{ Simpson } & 1 & p_shrub8 & 358.54 \\
\hline & 2 & p_shrub8 $+F H D$ & $\underline{354.33}$ \\
\hline & 3 & p_shrub8 $+F H D+H \_A V G$ & $\overline{355.92}$ \\
\hline & 4 & $\begin{array}{l}\text { p_veg }+p \_c a n o p y 15+F H D+ \\
H \_A V G\end{array}$ & 357.43 \\
\hline \multirow[t]{3}{*}{ Shannon } & 1 & p_shrub8 & 619.96 \\
\hline & 2 & p_shrub8 $+F H D$ & $\underline{612.25}$ \\
\hline & 3 & $F H D+p \_v e g+p \_c a n o p y 5$ & $\overline{611.12}$ \\
\hline \multirow[t]{4}{*}{ SpeciesN } & 1 & p_shrub8 & $\mathbf{1 4 2 7 . 8 5}$ \\
\hline & 2 & p_shrub8 $+F H D$ & $\overline{1427.87}$ \\
\hline & 3 & $F H D+p \_v e g+p \_c a n o p y 5$ & 1429.95 \\
\hline & 4 & $\begin{array}{l}\text { p_shrub8 }+F H D+p \_v e g+ \\
\text { p_canopy5 }\end{array}$ & 1432.03 \\
\hline
\end{tabular}

TABLE V

THE BEST LIDARMODELS FOR EACH DIVERSITY METRIC BASED ON BEST SUBSET REGRESSION WITH ONE TO SIX ALLOWED PREDICTOR VARIABLES.

\begin{tabular}{l|ll|lc|lc}
\multicolumn{2}{c}{ Simpson } & \multicolumn{3}{c}{ Shannon } & \multicolumn{2}{c}{ SpeciesN } \\
\hline variable & Estimate & $\begin{array}{c}\text { Std. } \\
\text { error }\end{array}$ & Estimate & $\begin{array}{c}\text { Std. } \\
\text { error }\end{array}$ & Estimate & $\begin{array}{c}\text { Std. } \\
\text { error }\end{array}$ \\
\hline Intercept & 0.003 & 0.16 & -0.25 & 0.25 & 1.51 & 0.21 \\
p_shrub8 & 0.51 & 0.12 & 1.32 & 0.19 & 4.80 & 0.61 \\
FHD & 0.38 & 0.12 & 0.57 & 0.18 & --- & $\ldots$ \\
\hline \hline
\end{tabular}

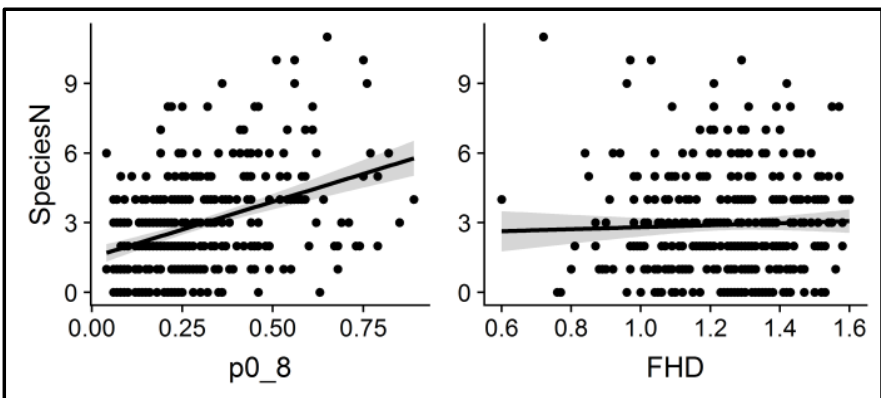

Fig 2. Linear relationships between species richness (Species $N)$ and the two best lidar-based predictors, the amount of understorey between ground and eight metres (p_shrub8, $r=0.39, p<0.001$ ) and the diversity of how vegetation is spread across the forest's full height profile $(F H D)$. The black line illustrates the line of best fit and the grey polygons depict the standard errors. FHD alone did not correlate with the response $(r=0.01, p=0.002)$, but its inclusion in the models with $p \_s h r u b 8$ always resulted in lower AIC.

\section{B. Hyperspectral metrics and avian diversity}

The two hyperspectral predictors identified most commonly as the best predictors of avian diversity were Vogelmann's Red Edge Index 2 (VOG2) and reflectance at wavelength $830 \mathrm{~nm}$ (r830). Other indices that served as good predictors were Rededge Enhanced NDVI (RENDVI), Plant Senescence Reflectance Index (PSRI), Anthocyanin Reflectance Index 1 (ARII), Water Index (WI) and Structure Insensitive Pigment Index (SIPI) (Table VI). Out of the hyperspectral metrics, the best relationships with the diversity metrics were achieved by VOG2_max, with $\mathrm{r}=0.21$ for SpeciesN, 0.16 for Shannon and 0.03 for Simpson ( $\mathrm{n}=333, \mathrm{p}<0.05$ in all cases). After the best subset regression and AIC comparison, it was only VOG2_max and r830_max that remained in the final HyperModels (Table VII) for all the metrics of avian diversity.

The maximum values of both VOG2 and $r 830$ had positive relationships with avian diversity. The values of VOG2 are sensitive to the combined effects of the canopy's leaf area, water content and chlorophyll concentration: the higher the values, the better the canopy's state, and the more it may offer for birds. Figure 3 shows the linear relationship between the best predictors and SpeciesN.

\section{TABLE VI}

THE RESULTS FROM BEST SUBSET REGRESSION WHERE BIRD DIVERSITY METRICS WERE MODELLED WITH HYPERSPECTRAL PREDICTORS

(HYPERMODELS). THE SUBSET NUMBER INDICATES THE NUMBER OF VARIABLES ALLOWED, AND THE VARIABLES LISTED FOR THAT MODEL WERE SELECTED AS THE MOST POWERFUL PREDICTORS BASED ON EXHAUSTIVE SEARCH. ALL PREDICTORS ARE SIGNIFICANT AT P $<0.05$. THE AIC VALUE OF THE FINAL MODEL IS UNDERLINED AND IN BOLD.

\begin{tabular}{|c|c|c|c|}
\hline Index & $\begin{array}{l}\text { Sub- } \\
\text { set }\end{array}$ & Formula & $\begin{array}{l}\text { Model } \\
\text { AIC }\end{array}$ \\
\hline Simpson & 1 & r830_max & 355.18 \\
\hline \multirow[t]{6}{*}{ Shannon } & 1 & VOG2_max & 662.45 \\
\hline & 2 & VOG2_max + r830_max & $\underline{658.50}$ \\
\hline & 3 & VOG2_max + r830_max + ARI1_min & $\overline{657.93}$ \\
\hline & 4 & $\begin{array}{l}\text { WI_avg + PSRI_avg + RENDVI_min + } \\
\text { r830_max }\end{array}$ & 656.81 \\
\hline & 5 & $\begin{array}{l}\text { VOG2_max }+ \text { VOG1_min }+ \\
\text { RENDVI_min }+ \text { r830_max }+ \text { ARII_min } \\
\text { VOG2__max }+ \text { SIPI_min }+\end{array}$ & 657.76 \\
\hline & 6 & $\begin{array}{l}\text { RENDVI_min }+ \text { r830_max }+ \text { ARII_min } \\
+ \text { WI_max }\end{array}$ & 658.23 \\
\hline \multirow[t]{6}{*}{ SpeciesN } & 1 & VOG2_max & 1468.51 \\
\hline & 2 & VOG2_max + r830_max & $\underline{1461.57}$ \\
\hline & 3 & VOG2_max + r830_max + ARI1_min & $\overline{1461.15}$ \\
\hline & 4 & $\begin{array}{l}\text { r830_max + PSRI_avg + RENDVI_min } \\
+ \text { WI_avg }\end{array}$ & 1459.80 \\
\hline & 5 & $\begin{array}{l}\text { r830_max }+ \text { RENDVI_min }+ \text { WI_avg + } \\
\text { VOG2_max }+ \text { ARI1_min }\end{array}$ & 1461.30 \\
\hline & 6 & $\begin{array}{l}\text { r830_max + RENDVI_min + WI_avg + } \\
\text { VOG2_max }+ \text { ARII_min }+ \\
\text { SIPI_min }\end{array}$ & 1459.76 \\
\hline
\end{tabular}

TABLE VII

THE BEST HYPERMODELS FOR EACH DIVERSITY METRIC BASED ON BEST SUBSET REGRESSION WITH ONE TO SIX ALLOWED PREDICTOR VARIABLES.

\begin{tabular}{c|cc|cc|cc}
\hline \hline \multicolumn{3}{c}{ Simpson } & \multicolumn{2}{c}{ Shannon } & \multicolumn{2}{c}{ SpeciesN } \\
\hline Variable & Estimate & $\begin{array}{c}\text { Std. } \\
\text { error }\end{array}$ & Estimate & $\begin{array}{c}\text { Std. } \\
\text { error }\end{array}$ & Estimate & $\begin{array}{c}\text { Std. } \\
\text { error }\end{array}$ \\
\hline Intercept & 0.39 & 0.12 & 1.20 & 0.34 & 4.86 & 1.12 \\
r830_max & 0.0004 & 0.0002 & 0.001 & 0.0003 & 0.0004 & 0.0001 \\
VOG2_max & --- & --- & 6.53 & 1.99 & 29.04 & 6.67 \\
\hline \hline
\end{tabular}

\section{Combined hyperspectral and lidar metrics and avian diversity}

When the best predictors were combined, the single dominant metric in predicting avian diversity was the lidar variable p_shrub8, followed by FHD, p_veg and p_canopy 15 . With hyperspectral data, the best predictors were r830_max, ARII_min and VOG2_max. The models, depending on the 


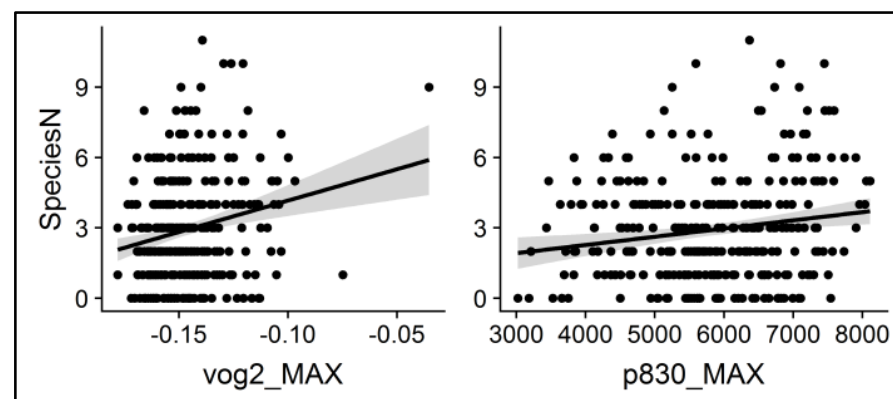

Fig 3. Linear relationships between species richness (SpciesN) and the two best hyperspectral-based predictors, Vogelmann's Red Edge Index 2 (VOG2_max, $r=0.21, p<0.001)$ and the reflectance at wavelength $830 \mathrm{~nm} .(r=0.17, p<$ 0.001 )The black line illustrates the line of best fit and the grey polygons depict the standard errors.

response variable, differed in how many variables they allowed when selecting the best model. For the Simpson index, the best model included four lidar variables with no hyperspectral variables. For the Shannon index and species richness (Species $N$ ), the best models were combinations of both lidar and hyperspectral variables. Table VIII shows the full results from the best subset regression, while Table IX shows the best CombiModels for each diversity metric as rated by AIC score.

\section{TABLE VIII}

THE RESULTS FROM BEST SUBSET REGRESSION WHERE BIRD DIVERSITY METRICS WERE MODELLED WITH LIDAR- AND HYPERSPECTRAL BASED PREDICTORS (COMBIMODELS). THE SUBSET NUMBER INDICATES THE NUMBER OF VARIABLES ALLOWED, AND THE VARIABLES LISTED FOR THAT MODEL WERE SELECTED AS THE MOST POWERFUL PREDICTORS BASED ON EXHAUSTIVE SEARCH. ALL PREDICTORS ARE SIGNIFICANT AT P $<0.05$. THE AIC VALUE OF THE FINAL MODEL IS UNDERLINED AND IN BOLD.

\begin{tabular}{|c|c|c|c|}
\hline Index & $\begin{array}{l}\text { Sub- } \\
\text { set }\end{array}$ & Formula & $\begin{array}{l}\text { Model } \\
\text { AIC }\end{array}$ \\
\hline \multirow{5}{*}{ Simpson } & 1 & p_shrub8 & 347.11 \\
\hline & 2 & p_shrub $8+F H D$ & 339.10 \\
\hline & 3 & $p \_s h r u b 8+$ FHD + H_AVG & 336.88 \\
\hline & 4 & p_veg + p_canopy $15+F H D+H \_A V G$ & $\underline{334.58}$ \\
\hline & 5 & $\begin{array}{l}\text { H_AVG+p_veg }+ \text { p_canopy15 + ARII_max } \\
+ \text { CRI1_avg }\end{array}$ & 333.98 \\
\hline \multirow[t]{4}{*}{ Shannon } & 1 & p_shrubs & 619.96 \\
\hline & 2 & p_shrub8 + r830_max & 608.77 \\
\hline & 3 & p_shrub8 + r830_max + ARII_min & 604.34 \\
\hline & 4 & p_shrub8 + FHD + r830_max + ARI1_min & $\underline{600.06}$ \\
\hline \multirow[t]{5}{*}{ SpeciesN } & 1 & p_shrub8 & $\overline{1416.43}$ \\
\hline & 2 & p_shrub8 + r830_max & 1400.92 \\
\hline & 3 & p_shrub8 + r830_max + ARII_min & 1397.23 \\
\hline & 4 & $\begin{array}{l}\text { p_shrub8 }+ \text { r830_max }+ \text { ARI1_min }+ \\
\text { VOG2_max }\end{array}$ & 1394.38 \\
\hline & 5 & $\begin{array}{l}\text { p_veg }+ \text { p_canopy } 5+r 830 \_m a x+A R I 1 \_ \text {min } \\
+ \text { VOG2_max }\end{array}$ & $\underline{1392.19}$ \\
\hline
\end{tabular}

\section{DISCUSSION}

This study focused on comparing hyperspectral-based metrics of foliage characteristics and lidar-based metrics of forest structure in explaining avian diversity. All the data were collected during the same summer and at a phenological stage where any stress induced by pests, drought, etc. would be visible and thus detectable from hyperspectral data. In addition, at this stage it was expected that issues in canopy condition caused by drought, for instance, would also be seen in the bird's habitat use.

Of published papers assessing avian diversity and the issue of floristics vs vegetation structure, Müller et al. [31] found lidar-derived metrics of vegetation structure (canopy height, density of mid- and understorey layers) to be dominant over metrics of plant species composition (field-based estimates of cover/abundance of different plant and tree species). Contrary to this, Rotenberry [14] found that field-measured variables of floristics (plant taxonomic composition) explained more than half $(55 \%)$ of the variation in bird community composition, while measures of vegetation structure explained significantly less $(35 \%)$. Vegetation structure in that study was fieldmeasured and accounted for vertical density of the vegetation as well as an index of overall horizontal spatial heterogeneity. However, White et al. [57] suggested that the role of both factors (floristics and structure) is dependent on the spatial scale of the analyses. Similarly, Landi et al. [58] and Hewson et al. [12] found that both floristics and vegetation structure were significant in explaining bird community composition. One key factor that may be important in the strength of the relationships between birds and canopy characteristics could be the degree of contrast within the data. For example, there may be clear differences between conifer and broadleaved trees but much less between different species of broadleaf or conifer. Most prior studies comparing bird occurrence or diversity with floristics have concentrated on tree species identity or composition. In our study, we have used hyperspectral variables that have previously been linked with tree health or species separation, but we have not directly attributed these variables to specific ecological measures within the study sites. Bird/habitat relationships may also be influenced by bird population sizes at the time of the study; for example, when numbers are high, habitat discrimination may be less apparent.

TABLE IX

THE BEST COMBIMODELS OF AVIAN DIVERSITY BASED ON BEST SUBSET REGRESSION WITH ONE TO SIX PREDICTOR VARIABLES. ALL VARIABLES ARE SIGNIFICANT AT P < 0.05

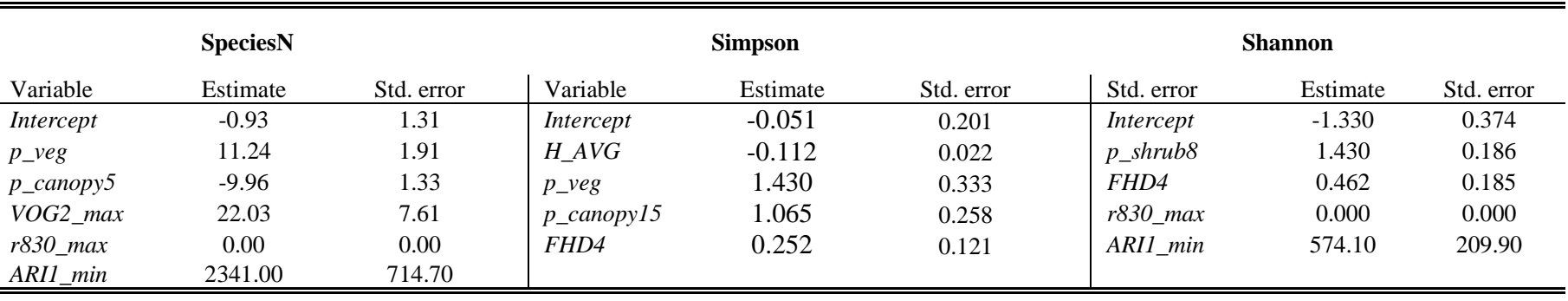


In this study, the variables of vegetation structure that best explained avian diversity, $F H D$ and $p_{-}$shrub8, are similar to those noted elsewhere to be useful when assessing wildlife habitats or questions related to diversity. In previous work, Clawges et al. [30] noted positive relationships between lidarbased $F H D$ and bird species diversity, while Rechsteiner et al. [37] found lidar-based estimates of average vegetation height, shrub density and canopy height to improve conservation planning for Hazel grouse (Bonasa bonasa), specifically at the local scale where fine-grained features of habitat structure mattered the most. Similarly, Melin et al. [22] showed lidarbased estimates of understorey density to be the most significant predictors of brood occurrence for three different grouse species in boreal forests. Flashpohler et al. [59] found that floristic and structural variables both affected bird occurrence significantly, although canopy height was the single best variable. Additionally they emphasized that the structure of the understorey layer is also a significant determinant of habitat quality, but one that is difficult to measure in the field; a task for which lidar has proven very useful.

The canopy foliage variables that were deemed significant here have been noted as useful in assessing the condition or health of forests $[60,61]$, yet have not been fully exploited in studies assessing wildlife habitats or diversity. The most important hyperspectral metrics were related to the properties of the canopy, such as moisture and chlorophyll content, the amount of leaf biomass (VOG2_max [43]), and leaf stress (ARII_min [62]). These, in turn, translate into ecologically meaningful attributes: e.g. compared to a stressed and dry canopy, a healthier one with dense leaf layers would offer the birds more resources such as seeds, flowers, insects and places for nesting. The other significant variable with positive relationships with avian diversity $(r 830)$ has been noted as useful in separating the dominant tree species from one another in this geographical area [24].

Overall, the relationships achieved in this study between individual metrics and diversity were moderate, yet in line with past studies. Müller et al. [31] used Mantel tests between matrices of bird species composition and variables of forest structure and floristics. Depending on the variable, they achieved correlations between 0.11 and 0.44 (the strongest correlations being with structural variables). In their fragmented study area, Flashpohler et al. [59] found bird species richness to increase in relation to patch size and tree volume in the patch (significant correlations between 0.06 and 0.86). This suggests that while shrub cover, for instance, has a significant role as a determinant for avian diversity, no single variable can explain all the variation. Indeed, despite individual lidar metrics, $p_{-}$shrub 8 and $F H D$, outperforming the hyperspectral metrics, the best models of avian diversity in terms of species richness (Species $N$ ) and Shannon index were the CombiModels. Only when predicting Simpson index was the best model composed of lidar-based predictors alone. As the foliage characteristics recorded by hyperspectral indices are likely to vary with tree species, this supports the views that both forest structure and floristics play a role in supporting avian diversity [57-58, 63-64].

Carter and Knapp [56] suggested that there is unrealized potential in what remote sensing could provide for biodiversity conservation, which they attributed to a potential mismatch between what the conservation community needs and what the remote sensing community has produced so far. Results from this and other studies show that a number of different remote sensing technologies can provide valuable ways of studying forest ecology. However, lidar has more potential in providing conservationists and wildlife managers with the information that can be translated into conservation action. Lidar data describe the physical structure of the habitat, for example the importance of a dense understorey layer, which can be manipulated by habitat management [37]. The situation is also improved by the facts that a time-lag between the acquisition of field ecology data and lidar data is not a fundamental source of error for conservation planning [65-66], and lidar data coverage is increasing continuously due to national or regional scanning campaigns in many parts of the world [67].

In conclusion, the two data types examined (lidar and hyperspectral) provide different information about the drivers of avian diversity. For the three measures of bird diversity assessed here (Shannon, Simpson and SpeciesN) the best fit models contained both lidar and hyperspectral derived measures. However, while both information sources are valid and worth utilizing when available, it was notable that for all three bird diversity measures the lidar only models outperformed the hyperspectral only models and the inclusion of hyperspectral data resulted in only minor improvements over the models created using lidar data only. Therefore, while there may be other contexts (e.g. detection of disease) in which hyperspectral data are more important, both data types (lidar and hyperspectral) are not necessarily needed for the assessment of diversity, with lidar frequently being more readily available and accessible.

\section{REFERENCES}

[1] J. Eitel, B. Höfle, L.A. Vierling et al. "Beyond 3-D: The new spectrum of lidar applications for earth and ecological sciences," Remote Sensing of Environment, Vol. 186, pp. 372-392. 2016.

[2] A.B. Davies and G.P. Asner, "Advances in animal ecology from 3D-LiDAR ecosystem mapping," Trends in Ecology \& Evolution, Vol. 29, No. 12, pp. 681-691. 2014.

[3] R.A. Hill, S.A. Hinsley and R.K. Broughton, "Assessing habitats and organism-habitat relationships by airborne laser scanning," In Forestry Applications of Airborne Laser Scanning: Concepts and Case Studies. M. Maltamo, E Næsset, and J. Vauhkonen (Eds.), Springer Netherlands, Dordrecht, The Netherlands, pp. 335-356. 2014.

[4] A.C. Newton, R.A. Hill, C. Echeverria, D.J. Golicher, J.M.R. Benayas, L. Cayuela and S.A. Hinsley, "Remote 
sensing and the future of landscape Ecology," Progress in Physical Geography, Vol. 33, No. 4, pp. 528-546. 2009.

[5] V. Kati, P. Devillers, M. Dufrêne, A. Legakis, D. Vokou and P. Lebrun, "Testing the value of six taxonomic groups as biodiversity indicators at a local scale," Conservation Biology, Vol. 18, pp. 667-675. 2004.

[6] R.D. Gregory and A. van Strien, "Wild bird indicators: using composite population trends of birds as measures of environmental health," Ornithological Science, Vol. 9, pp. 3-22. 2010.

[7] R.H. MacArthur and J.W. MacArthur, "On bird species diversity," Ecology, Vol. 42, No. 3, pp. 594-598. 1961.

[8] M.F. Willson, "Avian community organization and habitat structure," Ecology, Vol. 55, pp. 1017-1029. 1974.

[9] O. Hilden, "Habitat selection in birds," Annales Zoologici Fennici, Vol. 2, pp.53-75. 1965.

[10] N. Brokaw, R. Lent, "Vertical structure" In Maintaining Biodiversity in Forest Ecosystems, M. L. Hunter Jr. (Ed.), Cambridge University Press, Cambridge, UK. pp. 373399. 1999.

[11] L.A. Venier and J.L. Pearce, "Boreal forest landbirds in relation to forest composition, structure, and landscape: Implications for forest management," Canadian Journal of Forest Research, Vol. 37, No.7, pp. 1214-1226. 2007.

[12]C.M. Hewson, G.E. Austin, S.J. Gough and R.J. Fuller. Species-specific responses of woodland birds to standlevel habitat characteristics: The dual importance of forest structure and floristics. Forest Ecology and Management, Vol. 261, No. 7, pp.1224-1240. 2011.

[13]E. Fleishman and R. Mac Nally, "Patterns of spatial autocorrelation of assemblages of birds, floristics, physiognomy, and primary productivity in the central Great Basin, USA," Diversity and Distributions, Vol. 12, pp. 236-243. 2006.

[14] J.T. Rotenberry, "The role of habitat in avian community composition: Physiognomy or floristics?" Oecologia, Vol. 67, pp. 213-17. 1985.

[15] M. Maltamo, E. Næsset and J. Vauhkonen, Forestry Applications of Airborne Laser Scanning: Concepts and Case Studies. Springer Netherlands, Dordrecht, The Netherlands. 2014.

[16] P.S. Thenkabail, J.G. Lyon and A. Huete, Hyperspectral remote sensing of vegetation. CRC Press, Taylor \& Francis Group. 2012.

[17] J. Müller and K. Vierling, "Assessing biodiversity by airborne laser scanning," In Forestry Applications of Airborne Laser Scanning: Concepts and Case Studies. M. Maltamo, E Næsset, and J. Vauhkonen (Eds.), Springer Netherlands, Dordrecht, The Netherlands, pp. 357-374. 2014.

[18] R.A. Hill and R.K. Broughton, "Mapping the understorey of deciduous woodland from leaf-on and leaf-off airborne LiDAR data: A case study in lowland Britain," ISPRS Journal of Photogrammetry and Remote Sensing, Vol. 64, No. 2, pp. 223-233. 2009.

[19] F. Morsdorf, A. Mårell, B. Koetz et al. "Discrimination of vegetation strata in a multi-layered Mediterranean forest ecosystem using height and intensity information derived from airborne laser scanning," Remote Sensing of Environment, Vol. 114, pp. 1403-1415. 2010.
[20] M. Melin, L. Korhonen, M. Kukkonen and P. Packalen, "Assessing the performance of aerial image point cloud and spectral metrics in predicting boreal forest canopy cover," ISPRS Journal of Photogrammetry and Remote Sensing Vol. 129, pp. 77-85. 2017

[21]F. Zellweger, T. Roth, H. Bugmann and K. Bollmann. "Beta diversity of plants, birds and butterflies is closely associated with climate and habitat structure," Global Ecology and Biogeography, Vol. 26, pp. 898-906. 2017

[22] M. Melin, L. Mehtätalo, J. Miettinen, S. Tossavainen and P. Packalen, "Forest structure as a determinant of grouse brood occurrence - An analysis based on integration airborne LiDAR data to presence/absence field data" Forest Ecology and Management, Vol. 380, pp. 202-211. 2016.

[23] M. Melin, S.A. Hinsley, P.E. Bellamy, R.K. Broughton and R.A. Hill, "Living on the edge: utilising lidar data to assess the importance of vegetation structure for avian diversity in fragmented woodlands and their edges," Landscape Ecology, Vol. 33, No. 6, pp. 895-910. 2018

[24] R.A. Hill, G.M. Wilson and S.A. Hinsley. Mapping tree species in temperate deciduous woodland using timeseries multi-spectral data. Applied Vegetation Science, Vol. 13, pp. 86-99. 2010.

[25]T.G. Jones, N.C. Coops and T. Sharma, "Assessing the utility of airborne hyperspectral and LiDAR data for species distribution mapping in the coastal Pacific Northwest," Remote Sensing of Environment, Vol. 114, pp. 2841-2852. 2010.

[26] H. Hadi, M. Pfeifer, L. Korhonen, C. Wheeler and M. Rautiainen, "Forest canopy structure and reflectance in humid tropical Borneo: A physically-based interpretation using spectral invariants". Remote Sensing of Environment, Vol. 201, pp. 314-330. 2017

[27] L.C. Lepine, S.V. Ollinger, A.P. Ouimette and M.E. Martin, "Examining spectral reflectance features related to foliar nitrogen in forests: Implications for broad-scale nitrogen mapping," Remote Sensing of Environment, Vol. 173, pp. 174-186. 2016.

[28] C.S.T. Daughtry, C.L. Walthall, M.S. Kim, E. Brown De Colstoun and J.E. Mcmurtrey III, "Estimating corn leaf chlorophyll concentration from leaf and canopy reflectance," Remote Sensing of Environment, Vol. 74, pp. 229-239. 2000.

[29] J. Peñuelas, R.O. Pinol, R. Ogaya and I. Filella, "Estimation of plant water concentration by the reflectance Water Index WI (R900/R970)," International Journal of Remote Sensing, Vol. 18, pp. 2869-2875. 1997.

[30]R. Clawges, K. Vierling, L. Vierling and E. Rowell, "The use of airborne lidar to assess avian species diversity, density, and occurrence in a pine/aspen forest". Remote Sensing of Environment, Vol. 112, No. 5, pp. 2064-2073. 2008.

[31] J. Müller, J. Stadler, and R. Brandl, "Composition versus physiognomy of vegetation as predictors of bird assemblages: the role of lidar," Remote Sensing of Environment Vol. 114, pp. 490-495. 2010.

[32] S. Goetz, D. Steinberg, R. Dubayah and B. Blair, "Laser remote sensing of canopy habitat heterogeneity as a predictor of bird species richness in an eastern temperate 
forest, USA," Remote Sensing of Environment, Vol. 108, No. 3, pp. 254-263. 2007.

[33] M. Melin, S.A. Hinsley, P.E. Bellamy, R.K. Broughton and R.A. Hill, "Capabilities of lidar- and satellite data in assessing the drivers of avian diversity in a fragmented landscape" IGARSS 2018 - 2018 IEEE International Geoscience and Remote Sensing Symposium, Valencia, Spain, 2018, pp. 6596-6599. doi: 10.1109/IGARSS.2018.8517491

[34] J.H. Marchant, BTO common birds census instructions, British Trust for Ornithology, Tring, U.K. 1983.

[35] P. Axelsson, "DEM generation from laser scanning data using adaptive TIN models," International Archives of Photogrammetry and Remote Sensing, Vol. 33, pp. 110117. 2000

[36] M.A. Warren, B.H. Taylor, M.G. Grant and J.D. Shutler, "Data processing of remotely sensed airborne hyperspectral data using the Airborne Processing Library (APL): Geocorrection algorithm descriptions and spatial accuracy assessment," Computers \& Geosciences, Vol. 64, pp. 24-34. 2014

[37] R. Richter and D. Schläpfer, Atmospheric / Topographic Correction for Airborne Imagery, ATCOR-4 User Guide, Version 7.2.0, ReSe Applications LLC Langeggweg 3, CH-9500 Wil, Sswitzerland. 2018.

[38]C.H. Rechsteiner, F. Zellweger, A. Gerber et al. "Remotely sensed forest habitat structures improve regional species conservation," Remote Sensing in Ecology and Conservation, 2017. doi:10.1002/rse2.46. 2017.

[39] A.E. Magurran, Measuring biological diversity. 2nd ed. Oxford, U.K. Blackwell Science Ltd. 2004.

[40] Rouse, J.W., Haas, R.H., Schell, J.A. and Deering, D.W. 1973. Monitoring vegetation systems in the Great Plains with ERTS. In 3rd ERTS Symposium, NASA SP-351 I, 309-317.

[41] A. Gitelson and M.N. Merzlyak, "Quantitative estimation of chlorophyll a using reflectance spectra: Experiments with autumn chestnut and maple leaves," Photochemistry and Photobiology, Vol. 22, pp. 247-252. 1994.

[42] L. Brown, J.M. Chen, S.G. Leblanc and J. Cihlar, " A shortwave infrared modification to the simple ratio for LAI retrieval in boreal forests: An image and model analysis," Remote Sensing of Environment, Vol. 71, pp. 16-25. 2000.

[43] J.E. Vogelmann, B.N. Rock and D.M. Moss, "Red edge spectral measurements from sugar maple leaves," International Journal of Remote Sensing, Vol. 14, pp. 1563-1575. 1993.

[44] A. Gitelson, Y. Zur, O. Chivkunova and M. Merzlyak, "Assessing carotenoid content in plant leaves with reflectance spectroscopy," Photochemistry and Photobiology, Vol. 75, No. 2, pp. 272-281. 2002.

[45]A. Gitelson, M. Merzlyak, M. and O. Chivkunova, "Optical properties and nondestructive estimation of anthocyanin content in plant leaves" Photochemistry and Photobiology Vol. 74, No. 1, pp. 38-45. 2001.

[46] J. Penuelas, F. Baret and I. Filella, "Semi-empirical indices to assess carotenoids/chlorophyll a ratio from leaf spectral reflectance," Photosynthetica, Vol. 31, No. 2, pp. 221-230. 1995.

[47] M.N. Merzlyak, A. Gitelson, O.B. Chivkunova and V.Y. Rakitin, "Non-destructive optical detection of pigment changes duringleaf senescence and fruit ripening," Physiologia Plantarum, Vol. 106, pp. 135-141. 1999.

[48] R.E. Hunt and B.N. Rock, "Detection of Changes in Leaf Water Content Using Near- and Middle-Infrared Reflectances," Remote Sensing of Environment, Vol. 30, No. 1, pp. 43-54. 1989.

[49]H. Akaike. 1974, "A new look at the statistical model identification," IEEE Transactions on Automatic Control, Vol. 19, No. 6, pp. 716-723. 1974.

[50]K.P. Burnham and D.R. Anderson, "Multimodel Inference - Understanding AIC and BIC in Model Selection," Sociological Methods \& Research, Vol. 33, No. 2, pp. 261-304. 2004.

[51]R Core Team (2018). R: A language and environment for statistical computing. $\mathrm{R}$ Foundation for Statistical Computing, Vienna, Austria. URL https://www.Rproject.org/.

[52] T. Lumley, "based on Fortran code by Alan Miller, leaps: Regression Subset Selection," R package version 3.0. https://CRAN.R-project.org/package=leaps. 2017

[53]L. Mehtätalo, Imfor: Functions for Forest Biometrics. R package version 1.2. http://CRAN.Rproject.org/package=lmfor. 2017

[54]H. Wickham, ggplot2: Elegant Graphics for Data Analysis. Springer-Verlag New York, 2009.

[55]C.O. Wilke, cowplot: Streamlined Plot Theme and Plot Annotations for 'ggplot2'. R package version 0.9.2. https://CRAN.R-project.org/package=cowplot. 2017

[56] B.O. Connor, C. Secades, J. Penner, R. Sonnenschein, A. Skidmore, N.D. Burgess, N.D and J.M. Hutton, "Earth observation as a tool for tracking progress towards the Aichi Biodiversity Targets," Remote Sensing in Ecology and Conservation, 2015. https://doi.org/10.1002/rse2.4 2015

[57] J.C. White, C. Gomez, M.A. Wulder and N.C. Coops, "Characterizing temperate forest structural and spectral diversity with Hyperion EO-1 data," Remote Sensing of Environment, Vol. 114, No. 7, pp. 1576-1589, 2015.

[58] J.A. Wiens and J.T. Rotenberry, "Habitat associations and community structure of birds in shrubsteppe environments," Ecological Monographs, Vol. 51, No. 1. 1981.

[59] R.J. Fuller and P. Rothery, "Temporal consistency in finescale habitat relationships of woodland birds during a period of habitat deterioration," Forest Ecology and Management, Vol. 289, pp. 164-174. 2013

[60] G.A. Carter and A.K. Knapp, "Leaf optical properties in higher plants: linking spectral characteristics to stress and chlorophyll concentration," American Journal of Botany, Vol. 88, No. 4, pp. 677-684. 2001.

[61] M.O. Smith, J.H. Nolan, S. Gullck, L.G. Eckhardt and R.D. Menard, "Use of aerial hyperspectral imaging for monitoring forest health," In: Connor, K. F., ed. 2004. Proceedings of the 12th biennial southern silvicultural research conference. Gen. Tech. Rep. SRS-71. Asheville, 
NC: U.S. Department of Agriculture, Forest Service, Southern Research Station. 2004.

[62] M. Landi, M. Tattini and K.S. Gould, "Multiple functional roles of anthocyanins in plant-environment interactions," Environmental and Experimental Botany, Vol. 119, pp. 4-17. 2015.

[63]D.J. Flaspohler, C.P. Giardina, G.P. Asner, P. Hart, J. Price, C.K. Lyons and X. Castaneda, "Long-term effects of fragmentation and fragment properties on bird species richness in Hawaiian forests," Biological Conservation Vol. 143, No. 2, pp. 280-288. 2010.

[64]H.A. Walker, "Floristic and physiognomy determine migrant landbird response to tamarisk (tamarix ramosissima) invasion in riparian areas," The Auk, Vol. 125, No. 3, pp. 520-531. 2008.

[65] K.T. Vierling, C.E. Swift, A.T. Hudak, J.C. Vogeler and L.A. Vierling, "How much does the time lag between wildlife field-data collection and LiDAR-data acquisition matter for studies of animal distributions? A case study using bird communities" Remote Sensing Letters, Vol. 5, No. 2, pp. 185-193. 2014.

[66] R.A. Hill and S.A. Hinsley "Airborne lidar for woodland habitat quality monitoring: exploring the significance of lidar data characteristics when modelling organismhabitat relationships" Remote Sensing, Vol. 7, pp. 34463466, 2015.

[67] M. Melin, A. Shapiro and P. Glover-Kapfer. Lidar for ecology and conservation. WWF Conservation Technology Series 1(3), WWF-UK, Woking, United Kingdom. 2017.

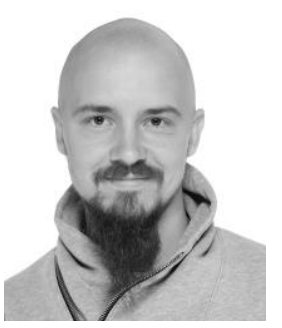

Markus Melin (IEEE member 1/2018) was born in Juva, Finland in May 1986. $\mathrm{He}$ received a $\mathrm{PhD}$ in Forest Sciences from University of Eastern Finland in 2016.

Since June 2018 he has been employed as a postdoctoral researcher at Natural Resources Institute Finland. Before this, he was a postdoctoral researcher at Bournemouth University, UK. His research focuses on the use of remote sensing to study the structure and configuration of forest environments and how this relates to wildlife research and management. He has also teaching- and field work experience from the related fields.

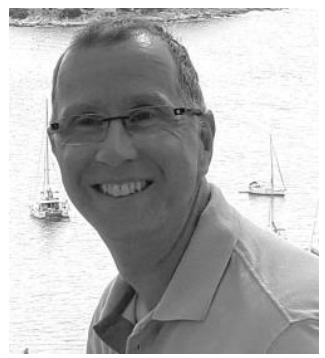

Ross A. Hill was born in Leicester, UK in 1971. He received a $\mathrm{PhD}$ in environmental remote sensing from the University of Wales Swansea, UK, in 1996.

$\mathrm{He}$ is a Professor in Environmental Remote Sensing in the Department of Life \& Environmental Science at Bournemouth University, in the UK.
At BU he has held the roles of Departmental Head of Research and Associate Dean of Education for the former School of Applied Sciences. Prior to arriving at BU in 2007 he spent 10 years at the Centre for Ecology and Hydrology (CEH) in the Earth Observation team. His research focusses on using remote sensed data to model forest structure, species composition, and turnover (i.e. regeneration, disturbance), in order to assess woodland condition, identify the factors determining habitat quality (especially for woodland birds and mammals) and evaluate how they change over time.

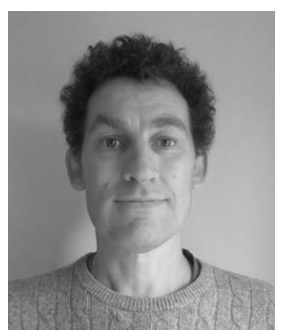

Paul E. Bellamy was born in Lee-onSolent, UK in 1961. He has worked in applied ecological research for more than 30 years after studying at Aberdeen \& Bangor Universities, UK. He is currently a Senior Conservation Scientist at the Royal Society for the Protection of Birds' Centre for Conservation Science, where he is the lead scientist for UK woodland research. Projects focus on action for birds of conservation concern and understanding forestry management and policy impacts on wildlife. Prior to this, he worked at the Centre for Ecology and Hydrology for 19 years, where a key area of research was on the impacts of landscape structure and habitat quality on woodland bird populations.

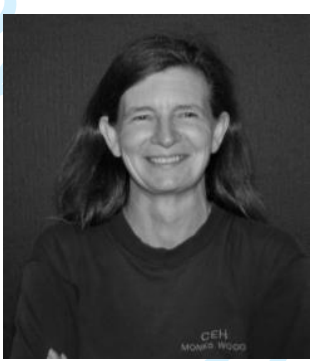

Shelley Hinsley received her PhD in Energetics of Desert Birds in 1990. She is an avian/landscape ecologist with over 35 years' experience of field ecology. For the last 28 years her work at the Centre for Ecology and Hydrology $(\mathrm{CH})$ has focussed on woodland and farmland bird population dynamics in relation to habitat fragmentation and landscape structure and how birds, from individuals to populations, respond to habitat modification. She has nearly 100 peerreviewed publications. In recent years she has been using airborne remote sensing to quantify habitat structure and composition as a means of quantifying bird/habitat relationships. She is a Chartered Biologist of the Royal Society of Biology and has served on Council and Committees of the British Ornithologists' Union (BOU). She retired in 2017 but continues her interests in ecology and remote sensing as a CEH Fellow. 